In Ochrida, Debra and other villages of this prefecture the suffering and want are more intense, although the number in each of these villages is much smaller. People, especially children and infants, are dying of starvation, and scenes of emaciation like those pictured in the China famine are by no means uncommon in the smaller settlements. Frightful as it may seem to be, it is no less true that starvation is running a very close race with disease in causing the heavy mortality which these people have experienced.

B. W. Caldwell, M.D.

Transparency of Abdominal Walls at Term

To the Editor:-In THF JournaL, July 31, 1915, p. 465, there is an abstract from a German obstetric and gynecologic journal. The article in question is by one Ahlfeld, and in this abstract the following sentence occurs:

In one woman [at term, he means] the walls [uterine] were so transparent that the different parts of the uterus, the ovaries and tubes conld be inspected with ease, and several graphic tracings were taken of the child's breathing [italics mine].

This gives me pause. I am prepared to concede almost anything to German efficiency. When I read that they were raiding the atmosphere for nitrogen, my hat was off to the achievement of the German scientist; but when I read that the German babies abstract oxygen from the amniotic fluid in utero, I feel like saying to the Allies, "Come on boys, call off the dogs ; put out the fire, and let's go home; it's no use." Or maybe the illustrious Teuton has discovered that the German fetus is equipped with gills. This assumption in a way seems plausible, for at times I am unable to tell if the Teuton is fish, or flesh, or fowl. Now I may be displaying British stupidity, but honestly, Doctor, do German babies breathe in utero, and if so, how?

W. W. Jarrell, M.D., Thomasville, Ga.

[Comment.-Ahlfeld's words in the original are: "Durch die verdünnten Bauchdecken sah man .. . die Nabelschnur liegend. Sehr schön waren die Atembewegungen des Kindes zu verfolgen, wie wenn das Kind unter einer leichten Decke läge." The fetal movements which later become the respiration movements of the child, are what he means. $\mathrm{He}$ refers to this in the first paragraph of the article, saying, "Während meiner Tätigkeit als Assistent und als Leiter einer Frauenklinik habe ich der äusseren Untersuchung Schwangerer und Gebärender ein ganz besonderes Interesse zugewendet; utm so mehr, nachdem ich auf die eigentümlichen fötalen Bewegungen aufmerksam wurde, die sich später als kindliche Atembewegungen herausstellten, und oft stundenlang Besichtigung des Leibes und Beolsachtungen der Vorgänge innerhalb desselben vornehmen musste." However, it would have been decidedly better if "Atembewegungen" had been translated "breathing movements."-ED.]

\section{Boston Park Shows}

To the Editor:-A new educational method has been introduced with success this summer in Boston. The problem of how to reach a large number of the population who seldom read, if they read at all, has been met with considerable success by what may be called "teaching with fun."

A committee was formed composed of representatives of the Antituberculosis Society, Boston Young Men's Christian Association and Young Men's Christian Union, the Women's Municipal League, Massachusetts Child Labor Committee, Milk and Baby Hygiene Association, Massachusetts Society for the Prevention of Cruelty to Animals, and the Poster Campaign Committee of the Associated Charities. These societies, united by their common interest in civic betterment and pullic health, cooperated in organizing and supporting the following plan: Each society subscribed $\$ 25$ and guaranteed another $\$ 25$ if necessary to meet the expenses. An active executive committee was formed. The plan was to lay out a program of moving picture shows, together with phonographic music, to be given five evenings in each week for a period of six weeks or more in the pleasure parks in different parts of the city. A program committee obtained interesting pictures and selected moving picture films which were hired; the program being varied every night. The committee secured the cooperation of some of the city departments, such as the Park Commission, and from private firms obtained the use of phonograph and records, and an automobile truck to transport the whole show. It was necessary to hire an operator and a manager who obtained the necessary permissions and saw that everything was ready and in place and made all immediate arrangements.

The programs were carefully arranged to give entertainment, and every third or fourth film or picture was educational.

It was estimated that during the first ten nights 60,000 people saw these shows. The shows began at $8: 15$ and lasted about two hours. Most of the people remained to see the whole performance and showed great enthusiasm at certain pictures, such as the weighing of a baby in a milk station.

The possibilities of public education appear to be very great through this form of entertainment. Since ignorance of hygiene and public health matters is one of the greatest difficulties which the physician meets today, we commend this form of education to the attention of the medical profession.

A. B. Emmons, 2D, M.D., Boston.

\section{Queries and Minor Notes}

Anonymous Communications and queries on postal cards will not be roticed. Every letter must contain the writer's name and address, but these will be omitted, on request.

\section{RHEUMATISM}

To the Editor:- What is the generally accepted opinion at present as to the cause of rheumatism, or what is rheumatism?

C. W. Ritter, M.D., McLean, Ill.

ANSWER.-The term "rheumatism" is perhaps the most loosely and carelessly used of medical words. It has been applied to such a varied array of human complaints that unless qualified by some descriptive term it may be said to have no meaning at all.

One of the most common diseases to which "rheumatism" is applied is acute articular rheumatism or "rheumatic fever" This is a fairly well-defined clinical entity, characterized by its occurrence usually in the young, its prolonged course, migratory invasion of joints, fever, sweating, etc. Even in this disease, the term "rheumatism" is expanded so as to describe some of the special features of the disease as well as the disease itself; for example, "cerebral rheumatism" and "cardiac rheumatism," by which are meant certain complications involving the brain or heart, arising from the infection, and not directly related to changes in the joints.

Multiple lesions of joints occur in certain of the infectious diseases. Gonorrheal rheumatism and scarlatinal rhenmatism express the superficial similarity of these processes to the form of joint disease named. The more exact terms "gonococcal arthritis," "periostitis" or "streptococcal arthritis" should, of course, now be used.

Other forms of multiple arthritis, more recently shown to be due to localization of micro-organisms resident in some focus of infection in the body, present clinical pictures which pass by slight grades of extent and severity of symptoms from those very similar to acute rheumatic fever to the more chronic deforming arthritides which hitherto have been placed in the heterogeneous collection called arthritis deformans, or rheumatoid arthritis.

In all of these, the use of the word "rheumatism" adds nothing but confusion, and the conditions might better bi described as acute or chronic arthritis, prefixing a more specific anatomic or bacteriologic title when such is possible. In extenuation of these uses of the word "rheumatism," we must in justice admit that many lesions of joints were first recognized clinically as associated with certain diseased conditions of other parts of the body (scarlatinat "rheumatism"), and that it is only by our more recently acquired knowledge of pathology and bacteriology that we are enabled to make more cleancut etiologic distinctions.

"Rheumatism" calls up in the minds of most of us various concepts associated with joint lesions, such as swelling, redness, heat, pain, disability, etc. Almost. any diseased state presenting one of these features as the prominent sign or 